\title{
Tactile topologies of the rural
}

\author{
Alistair Fraser \\ Department of Geography, Maynooth University, Ireland
}

\section{A R T I C L E I N F O}

\section{Article history:}

Received 9 August 2016

Received in revised form

8 March 2017

Accepted 3 October 2017

Available online 10 October 2017

\section{Keywords:}

Tactile topologies

Power topologies

Rurality

The state

South Africa

Herbert Gladstone

\begin{abstract}
A B S T R A C T
Innovative and exciting research by critical human geographers has brought tactility into focus. Seen against the backdrop of recent theorizing about power topologies, the prospect of novel analyses of contact, touch, and intimacy raises demanding questions for spatial theory. Action in rural space deserves attention within this emerging literature: if 'tactile topologies' are constitutive of space, a matter for research is how they emerge - and are drawn upon and re-produced - in the rural. This article's intervention is based on an exploration of the centrality of tactility to topological transformations in rural space during the first years of the Union of South Africa. Using archival materials alongside diverse contributions from historians, the article demonstrates how 'tactile topologies of the rural' animated and therefore shaped a wide range of calculations and actions. By focusing on 'intra-actions' between human and non-human actors within numerous 'microcalities,' the article prompts scholars in rural studies to imagine how a focus on tactility might enrich analyses of a wide range of other topological scenes.
\end{abstract}

() 2017 Elsevier Ltd. All rights reserved.

\section{Introduction}

Recent developments of topological thinking in critical human geography seek to explain how power - authority, say, or seduction - is made effective despite distances between affected actors (e.g. see Allen, 2003, 2011a, 2011b; Allen and Cochrane, 2010, 2014). Subsequent contributors have called for research that recognizes and theorizes the significant ways that humans and non-humans alike draw upon and create 'microcalities' and 'tactile topologies' that are necessarily constitutive of space (Dixon and Jones, 2015). These prompts for innovative research should, one might expect, bring rural spaces and the action unfolding there immediately to mind, although the broad thrust of topological theorizing in general and the more specific turn towards thinking about tactility have both displayed an implicit (and perhaps an unintentional) urban bias. Does a focus on tactile topologies offer anything for research in rural studies?

Toward providing an answer, the following article examines a case in which tactile topologies enlivened and shaped social debate, political deliberation, and economic calculation regarding rural change. My focus is on South Africa in the early twentieth century, which I access via use of contributions from diverse literatures, as well as materials held in the archive of Herbert J. Gladstone (1854-1930), who was Governor-General of the Union of South

E-mail address: alistair.fraser@nuim.ie.
Africa from 1910 to 1914. I use these materials to demonstrate the relevance of tactility, contact, and intimacy to processes of sociospatial change in general and rural action in particular. I argue that 'tactile topologies of the rural' animated state- and farmer-led actions designed to create a functioning settler capitalist space economy. Producing rurality meant negotiating contact.

The rest of the article is organized as follows. I first discuss the idea of tactile topologies in relation to topological conceptualizations of power, and then consider whether rural research on these issues should anticipate peculiarities regarding the importance of touch and contact. Second, I introduce and justify my use of Gladstone's archival materials, and then use them alongside insights gleaned from literature on this period of South African history to illuminate how tactile topologies came to matter. Finally, I draw conclusions from the preceding materials and highlight some ways that tactile topologies of the rural might be further researched in other contexts.

\section{Topology, power, touch, and the rural}

Understanding how power gets worked out in the context of shifting spatial arrangements is the crux of the matter when it comes to topological thinking in critical human geography. At issue are questions such as: How might a government official based in one place get something done in another place, even on the other side of the world, and amidst changing constellations of social relations? The point is that, despite vast distances and a wide range of 
unstable geographical configurations between them, some 'distant powers' are still able to dominate, manipulate, seduce or exert authority over others (on the different 'guises' of power, see Allen, 2003). The key to grasping this: their 'powers of reach,' that is, their capacity to alter social action from afar, even when interactions are stretched across space - when distances between objects grow and when a process of circulation hooks up and enrols others (Allen, 2011b: 298). Authority or influence may still be made effective, almost as if distance does not matter. Reach is powerful. The argument, therefore, is that scholars need to question how social relations are reconfigured, folded, or twisted into an arrangement that "enables distant actors to make their presence felt, more or less directly, 'here and there'" (Allen, 2011b: 290). Consequently, the concept of 'power topologies' (Allen and Cochrane, 2010; Allen, 2011a, 2011b) presents a way to think about and apprehend the sorts of arrangements that close the gap between here and there, reconfigure presence and absence, and allow actors to make change happen within complex and changing geographical configurations. Thus, when a non-governmental organization campaigns against sweatshop exploitation by linking working conditions to branded retailers, it works to dissolve distance and extend the 'reach' of consumer responsibility (Allen, 2008). This power topology of twists, stretching, or compression is fundamental to the way politics is played out. Focusing on power topologies can help us understand the roles played by those who have the capacity to decide how spatial arrangements are reconfigured, as well as those who oppose or subvert reconfiguring processes (e.g. see Allen and Cochrane, 2010). Topological approaches complicate but improve analyses of the production of space.

Against the backdrop of theories about power topologies - and the scope they present for analyses of the complexities of creating arrangements and configurations that enable presence/absence or reach to occur - a more recent development by Dixon and Jones (2015) has argued for attention to matters of contact, touch, and tactility. This line of inquiry proposes that topological thinking in critical human geography takes seriously how humans and nonhumans draw upon and create 'tactile topologies' that alter calculations about contemporary life. Using an analysis of the Hollywood film Contagion, Dixon and Jones bring to light the way in which "various materials and forces" come into contact, "grab onto each other," and then become the "engine of topological transformation" (p.223). What matters in these 'tactile topologies' is, per Hinchliffe et al. (2013), not so much the "shape and size of things or the distance between them [but rather the] relationships that tie them together" (p.538). In other words, it need not matter whether the relations are between humans and bacteria, bacteria and other bacteria, or between security arrangements and governance practices. Rather, the analytical question is how the relations respond and give rise to 'microcalities' (Dixon and Jones, 2015) that negotiate the fact and necessity of tactility. Such microcalities, in turn, generate to research questions about the "the ethico-politics of intimacy" with which humans must grapple, as well as numerous "corporeal vulnerabilities produced by irruptive, non-human life forms" (Dixon and Jones, 2015: 231), which constitute and surround human action but which have tended to be neglected amidst a widely-practised anthropocentrism in geography and the social sciences as a whole; in response, then, Dixon and Jones call for research that avoids adopting a "mind's eye [that] will tend to gloss both human and non-human tactilities and the swarming micros that pass between and among them" (p.231).

\subsection{Tactile topologies and rural space}

The tactile topologies Dixon and Jones (2015) prompt us to consider necessarily cross over and cut through urban and rural space. The same goes for power topologies more generally. Indeed, a novelty of topological thinking in geography is precisely the invitation to eschew 'bumpy' topographical concepts such as rural/ urban and instead embrace a flat ontology (Marston et al., 2005) that prioritizes relationality and asks how "relations are formed and then endure despite conditions of continual change" (Martin and Secor, 2014: 431; emphasis in original). Some scholars in urban studies decline that invitation and continue to embrace and theorise 'the city' (e.g. on urban density, see MacFarlane, 2016). Others use 'the city' and probe the meaning of urban politics, but emphasize how that politics reflects demands emanating from elsewhere, which therefore "suggests a different spatial register for the politics of the city; one that does not merely imagine that what happens elsewhere is connected to the polis, but rather conceives of the 'outside' as already folded into the political practices of the polis" (Allen and Cochrane, 2014: 1619). A 'different spatial register' also might have purchase in a topological approach to rural studies, especially in the context of a 'global countryside' (Woods, 2007) constituted by overlapping and entangled networks, and flows. Howsoever a rural politics takes shape will no doubt reflect this sense of relations from elsewhere 'folding into' the rural scene. Ultimately at issue are the relations connecting things together and how we might best approach an analysis of them.

Yet, although topological approaches in geography present the possibility of moving beyond a rural/urban frame, entirely jettisoning 'the rural' (or the urban) seems churlish in the face of an enduring politics - indeed, precisely a 'politics of the rural' (Woods, 2003) - shaped by diverse and contested representations, not to mention relations around rurality (or urbanity), that illuminate "material and discursive permanences [that] matter in people's everyday lives" (Heley and Jones, 2012: 215). As Enticott (2011) demonstrates regarding the neutralisation of badgers, for example, 'rural identities' and 'articulations of rurality' can meet up with and alter the state's powers of reach. And as examined in Jönsson's (2016) research on a Donald Trump golf course in northeast Scotland, the contested global countryside and representations of rurality shape how stretched and twisting power plays get worked out. Like the city, therefore, 'the rural' has an enduring politics which, precisely because it is a politics configured relationally, means it should remain open to topological approaches.

With regards to matters of tactility, I suggest there is another good reason for considering the rural in a topological frame. Livestock is reared in urban areas today, as indeed turns out to matter in Contagion (Dixon and Jones, 2015), but it is overwhelmingly a rural phenomena, even if some concentrated animal feeding operations are industrial in scale and radically depart from many taken-forgranted notions of what rurality entails (e.g. see Weis, 2013; also Allen and Lavua, 2015). In turn, the possibility of disease spreading between animals shapes how rural space is governed. Authorities, agencies, and government departments monitor, report, and intervene based on so-called 'biosecurity' threats (e.g. see Enticott, 2008; Hinchliffe et al., 2013; Hinchliffe and Ward, 2014; on biosecurity processes and 'circulations' more generally, see Barker, $2008,2015)$. At stake in times of 'biosecurity' crisis is the viability of diverse and (varyingly) interconnected actors in a livestock industry constituted by many farmers operating under "economic duress" (Hinchliffe and Ward, 2014: 140). In play is a set of relations that mobilises farmers, processors, retailers, as well as insurers and intermediaries extending credit or supplying feed or pharmaceuticals to act (Enticott, 2016; on similar pressures in the poultry sector, see Wilbert, 2006; Allen and Lavua, 2015). Material interests create pressure on the state to deploy its unique powers and, if needs be, intervene to reconfigure the topological scene. 
As such, rural spaces in which livestock production occurs emphatically not all rural spaces, therefore - occupy this peculiar position with respect to tactility. Albeit at the extreme end of things, 'topological transformation' (Dixon and Jones, 2015) in rural areas can be achieved by killing vast numbers of animal intermediaries (as indeed occurred in response to the Foot and Mouth Disease outbreak in the UK in 2001 [Scott et al., 2004; Law, 2006; Law and Mol, 2008]). In such a scenario, 'strategic compromises' (Enticott, 2008) around the 'ethico-politics of intimacy' (Dixon and Jones, 2015) re-calculate the economic and social value of livestock; and diverse state agencies and human actors, such as farmers (always, per Enticott [2008: 1579], 'managing contingencies'), proceed to re-calibrate these tactile topologies by radically (and violently, especially for species such as badgers exposed to culling [e.g. see Enticott, 2008]) altering the relations between all social objects (human and non-human).

At a more mundane level, too, there are the social practices, material arrangements, and spatial configurations that constitute rural space precisely because 'swarming micros' (Dixon and Jones, 2015) engender tactile topologies that threaten (/alter) the economic value of livestock and livestock production. At issue are the everyday and banal 'borderlands' made up of cattle dipping infrastructure; fences; monitoring and reporting protocols; and distant scientific communities enrolled to engage and navigate these tactile topologies of the rural (Enticott, 2008, 2012; Hinchliffe et al., 2013; Barker, 2015; Hinchliffe and Ward, 2014). As noted above, caught up in the action here are a wide range of public policies reflecting national laws and, in Europe at least, directives - that deal with contact and the potential that irruptive life forms might unsettle vast economic structures based on the (always temporary, because of the "open and emergent" [Barker, 2015: 363] causes of disease) existence of stable relations between humans, livestock, and bacteria. What we can find in some rural areas are artefacts and traces of these tactile topologies, the obvious importance of their management or negotiation, and the inevitable "patchwork" (Hinchliffe and Ward, 2014: 141) and 'patchings' (Enticott, 2012: 84) of material and institutional prompts and responses that have to shape, and get re-made, to keep stable a set of relations and arrangements that can seemingly turn bad at any moment. In rural space, then, simply as a result of the material interests shaping human-livestock relations, we can expect tactile topologies to generate a wide range of practices, including action and reaction, as well as experimentation with novel spatial arrangements. Considerations about contact and life pervade the engineering of a topological rurality potentially disrupted by irruptive microcalities over which humans have (perhaps momentarily) lost control. In making certain objects absent or present, or in reaching into distant areas to create some specific form of change, the state and a wide array of other players necessarily intermingle and negotiate this fluid set of relations, movements, and interests.

However, emphasizing these tactile topologies of the rural does not mean they operate in isolation; rather, I argue they need to be seen as 'intra-acting' with 'attempts at calculability' in the city (Barker, 2015: 360). For Hinchliffe et al. (2013: 537, drawing on Barad, 2007; see also Wilbert, 2006), the point of dwelling on 'intra-action' is that entities such as pathogens move and, as they do so, they alter, change, transform, and even transduce the 'entangled interplay' (Allen and Lavua, 2015: 357) of other objects and their varying arrangements. In the case of livestock production, and as we have seen, rural spaces unsettled by 'swarming micros' (Dixon and Jones, 2015) contingently yield responses that seek to engineer topological transformation - but these are responses that inevitably take into consideration and intra-act with matters 'folded in' (Allen and Cochrane, 2014) from the city. There are, for example, worries about the food supply or public health; and certainly financial calculations about the possible effects of widespread culling or other measures. Also caught up in matters shaping what happens in rural space are the interests of banks and investment funds, many of them headquartered in far-off cities. Then there are the supermarkets and urban sensibilities about food safety or provenance (that may, in some cases, hang on to outdated but widespread perceptions about how livestock in rural space is reared). Consequently, 'translation' (Hinchliffe and Ward, 2014) can be required to explain why specific measures must be taken, motivate decision-makers in political centres to undertake the requisite measures that can 'reach' into rural space, and even encourage urban-based actors to experiment with bold arrangements. Rural action is not always easily grasped; in an urban world like today's, in fact, it has arguably never been so hard to work out whether there is anything peculiar about the rural at all (cf. Brenner and Schmid, 2014). In looking for tactile topologies of the rural, therefore, and as I noted earlier, the analytical gaze must by necessity drift towards the city and incorporate a consideration of what matters there; how and why it shapes rural space; how it drifts or gets folded into rural imaginaries, representations, and politics.

As I now move on to discuss, just such a mix of 'intra-acting' topological factors and calculations about rural space was at work in the first few years of the Union of South Africa. Questions of how the state and other actors might find ways of grappling with the 'ethico-politics' of 'swarming micros' (Dixon and Jones, 2015) animated political and bureaucratic debate and deliberation in this period. For actors such as Herbert Gladstone, South Africa's future prospects hinged on making the appropriate 'strategic compromises' (Enticott, 2008) that would calibrate the topological scene, stabilize irruptive life, and make it possible for new livestock production systems to emerge. Furthermore, as I elaborate below, ideas and imaginaries about how these possible solutions and practices might appear closely overlapped with, and were made sense relative to, urban dynamics at the time. Overall, as I believe my treatment of the following materials demonstrates, tactile topologies of the rural, bound up with racialised dynamics of intimacy, were central to the project of creating a space in which Europeans could prosper. Ultimately what I should like to suggest is that this period of South Africa's geo-historical development presents an appropriate case study of tactile topologies of the rural emerging to become central to a broad range of social, economic, and political calculations about the constitution of space and the contested production of the future. Toward illuminating these issues, therefore, I turn now to introduce and then use materials from the archive of Herbert Gladstone.

\section{Tactile topologies and the production of South Africa's rural economy}

Herbert Gladstone was the youngest of the eight children born to William E. Gladstone (1809-1898), one of nineteenth century Britain's foremost politicians (Jenkins, 1995). Herbert followed his father into parliament in 1880, after winning at Leeds (Mallet, 1932). His father finally had "a son who had achieved a First, who had won a sparkling victory at Leeds [and] who looked capable of shouldering the Gladstone future" (Bentley, 1992). 'Capable' he may have been, but he was destined to have a mediocre political career. Although he had served the Liberal Party significantly, for example as Chief Whip in opposition from 1899 to 1905, he did not join the Cabinet until 1906. Hoping to lead the admiralty in Cabinet, Gladstone was instead appointed as Home Secretary under the Campbell-Bannerman and then Asquith Liberal governments (Mallet, 1932). He was not counted by Asquith among the many talented ministers in a strong Liberal Cabinet (Jenkins, 1978). His 
was a "tenure more subdued than glorious" (Bentley, 1992: 901), underscored by his failure to carefully and decisively deal with a controversial Eucharistic procession in London, an experience which undermined his reputation for competent administration, and gave rise to protests from King Edward VII when Prime Minister Asquith appointed Gladstone as Governor-General to the new Union of South Africa, an appointment for which Winston Churchill was a contender (Jenkins, 1978: 212-213).

While in South Africa, Gladstone's principal role was to support the first Union government, liaise with its main actors - especially the Prime Minister, Louis Botha, and his deputy, Jan Smuts - and lead the imperial administration toward more effective governance. His five years of experience as Home Secretary in London gave him confidence that he could improve (what he frequently referred to as) the 'machinery of government' in South Africa. A few key events occurred during his time in the country, perhaps most notably the strikes by white mine and railway workers in July 1913 and January 1914. My use of the archive has especially focused on these critical incidents, in part because during these moments he made quite lucid notes about the country, not least in dispatches to Loulou Harcourt (1863-1922), who was Secretary of State for the Colonies, 1910-15 (on Harcourt, see Jackson, 2006). In analyzing his notes on these incidents, I follow a point made by the historical geographer Miles Ogborn, who noted that artists who were among the first British people to encounter the Pacific islands "had to cut into the flow of events to draw out an enduring image that could stand for much more than just that moment" (Ogborn, 2008: 314). Depictions of peoples and landscapes were to be shown to others, that is, archived and used later on. In my view, Gladstone (and others like him) should be seen as having done the same: certainly, Gladstone intended to leave an archive, hence his work of collecting, recording, and depositing materials was a form of representation that also had to 'cut into the flow of events.' In what follows, then, I use some of these 'cuttings' - including views as expressed by Gladstone, but also some of the materials to which he had access and which he deposited in the archive - to reveal two ways that issues of tactility shaped processes of socio-spatial in rural South Africa.

\subsection{Livestock diseases and a government in the making}

Livestock were a critical component of the rural scene in South Africa (e.g. see especially Tilley, 2004; Gilfoyle, 2003; Brown, 2005; Brown and Gilfoyle, 2010; Mwatwara and Swart, 2015), as was the case in other parts of the British empire in Africa (e.g. see Waller, 2004; Sunseri, 2013) and in India (e.g. see Davis, 2008). One aspect was the centrality of livestock to the material circumstances of extant and prospective settlers: whether used for ploughing the land or reared to supply new urban markets, for example in the mining areas around Johannesburg, many settlers saw opportunities in livestock production. Then, another and related aspect was that, among Africans, cattle were also important, albeit in a slightly different way as more of "a store of wealth [as well as in] lobola (bride-wealth) transactions, ploughing and transport, and as suppliers of milk and manure" (Mwatwara and Swart, 2015: 115). The colonial encounter in South Africa therefore entailed and emerged via the co-existence, and in many cases the inter-dependence and indeed close proximity and overlap, of two 'livestock regimes' (Mwatwara and Swart, 2015). Precisely how these regimes came into contact with one another raised 'ethico-political' (Dixon and Jones, 2015) issues: for many settlers, "many of whom could not have fed themselves or their families were it not for the ingenuity and oxen of their African tenants" (Higginson, 2001: 109), African herds were simultaneously a 'dirty' (Waller, 2004) nuisance and a resource to be drawn upon and exploited.
Animal diseases considerably complicated all these matters. The two main diseases at issue in South Africa were diseases of "contact and dispersal" (Waller, 2004: 47), especially rinderpest and East Coast Fever (ECF). A rinderpest outbreak in the late 1890s had "produced a profound disruption of the economy of Rhodesia and South Africa, as well as creating widespread social tension and impoverishing many Africans. Transport was disrupted, shortages of food developed, and, in South Africa, many Africans were driven from the land and forced into the labor market" (Cranefield, 1991: 287). As Gilfoyle (2003) has discussed, the disease was eventually tackled by vaccination and strict quarantines, although the development of these capacities to intervene was far from straightforward: feuding scientists, resistance from settlers and Africans, and the limited 'reach' of veterinary policy all had to be overcome. But gradual progress was made and the experience of doing so gave South Africa a "significantly strengthened" (Gilfoyle, 2003: 154) veterinary service that had learned numerous lessons about how to re-configure spatial arrangements, adjust practices, and engage with diverse publics. In the terminology of Hinchliffe et al. (2013) and Dixon and Jones (2015), veterinary services learned how to better 'intra-act' with the 'swarming micros' that were - and intensely so - the 'engines of topological transformation' in rural South Africa.

By the time Gladstone arrived in the country, East Coast Fever (ECF) was the main threat to South Africa's two livestock regimes. The disease was transmitted to livestock by contact with the brown tick (Rhipicephalus appendiculatus). Given a lack of biomedical solutions, "the state resorted to an array of veterinary directives, including obligatory stock dipping, local quarantines and restrictions on animal movements" (Brown, 2005: 522). Thus, in recognizing the threat ECF faced to the material prospects of a Europeanizing agrarian sector, the state developed new powers of reach and calibrated its machinery to craft new spatial configurations and arrangements. In establishing quarantines, restricting cattle movements, or enacting new legislation to give veterinarians access to, and administrative power to govern, African-owned cattle (Brown, 2005), tackling the disease meant developing new forms of domination. The use of dipping, meanwhile, established new 'borderlands' (Hinchliffe et al., 2013) between 'clean' and 'dirty' animal husbandry practices; or, as Waller (2004: 51) characterised colonial attitudes (in Kenya), between "settlement and savagery, progress and stagnation." Not alone was dipping timeconsuming, it was also expensive and the costs were to be borne by owners, hence its efficacy was undermined given that this was a society intensely characterised by unequal capabilities and material circumstances among settlers and Africans (Brown, 2005: 522; also see Higginson, 2001: 109).

Gladstone was well aware of these issues. Some of the emerging complications were laid out to him, for example during a visit to Zululand in 1913 when he was told that, "East Coast Fever was either directly or indirectly responsible for most of the complaints of the natives" (Minute, June 27th 1913, The National Archives (TNA), CO551/41/205). The effects of the disease were not the only issue, however. Rather, he was told that,

They [Zulu Chiefs] resent the restrictions placed upon the movement of stock, which affect them in two ways. In the first place many of them have stock in infected areas far from their kraals, and they are deprived of the last despondent crumb of comfort - the privilege of 'eating their own dead meat'. Secondly, the suitors of their daughters can offer no lobola, since the beasts they have may not be moved, and when no suitor has an advantage on material grounds, the daughters claim the right of free choice (Minute, June 27th 1913, TNA, CO551/41/ 205-206). 
These sorts of 'intra-actions' (Hinchliffe et al., 2013) between the state and Africans altered how technologies could be used to deal with disease. As noted earlier, veterinarian knowledge at the time emphasized expanding the availability and use of dipping. But as Gladstone found out in Zululand, many Africans were "stolidly sceptical of the advantages of dipping. At every meeting speakers asserted that dipping was of no value, or even that stock, when dipped, died on the spot" (Minute, June 27th 1913, TNA, CO551/41/ 206-207). In other settings, Africans were prone to hide their cattle when Europeans approached, for fear of confiscation or sanction (Mwatwara and Swart, 2015: 132).

In the context of these complexities, Gladstone called on African leaders to re-imagine their role in society. In April 1913, for example, he called on Chiefs in Basutoland to remember that the Basuto,

.. have a duty to fulfill towards their country, this fair land which has been preserved to them for their habitation. They must learn to turn its advantages to the best account. It is the duty of all nations to improve the land which they have inherited from their fathers. As the population increases, more must be produced from the land [...] The Government has already done much to help and advise the Chiefs and people in improvement of their stock and their methods of agriculture. [...] The people must be taught to realise the importance of proper methods of tillage and of improving the quality of their horses, cattle and sheep. You say that you are backward in civilisation. It is by the study of farming rather than by the study of books that you will become civilised. Learn about your land first and about books afterwards (Gladstone speech to Swazi Chiefs, October 17th 1913, British Library (BL) AM/46113/239).

Later, in a speech to Swazi Chiefs in October 1913, Gladstone congratulated them on their "action for the extermination of East Coast Fever and other animal diseases by fencing and the provision of dipping tanks throughout the country" (Gladstone speech to Swazi Chiefs, October 17th 1913, BL, AM/46113/239). Classically paternalistic, patronising, and inherently racist: Gladstone's speeches demonstrated a lack of understanding about African livestock practices. Although there were instances of African livestock owners seeking out government support (Gilfoyle, 2003: 150), there was also, as Mwatwara and Swart (2015) note (albeit, regarding the Rhodesian context), significant opposition to "coercive veterinary interventions and policies" (p.117), in part because "state veterinary services were integral to an exploitative system they rejected" (p.138) but also, of course, because (quarantines and) slaughter policies robbed them of (using) a key source of wealth and pride (see also Brown, 2005: 522). In effect, Gladstone's representations to Africans were typical of a lazy and insensitive colonial attitude that could only imagine European solutions to animal diseases (Mwatwara and Swat, 2015: 116). For officials such as Gladstone, then, Africans had to be guided by Europeans, such that the topological context in which social relations emerged would be effectively altered: making absent what was otherwise present ('backward' ideas, say); or by re-shaping spatial configurations to extend the state's powers of reach (for example by empowering veterinary services to play a more active role among African cattle herders).

The interplay of the state, ticks - 'swarming micros' - and the country's two livestock regimes therefore gave rise to and emerged from the complex tactile topologies of the rural. And demanded diverse adjustments. The sorts of responses noted above and made by the veterinary services and then officials such as Gladstone were immediately and obviously proximate, nearby, local. But ECF (and the prospect of diseases like it) also demanded a response that reached far beyond South Africa. In this regard, it is striking that Gladstone responded in an ambitious spirit to animal diseases and their potential impact on rural development. His role in the country was, as he expressed it, "to preside at the birth of Union government [and be] in close association with your national life" (Gladstone speech in Cape Town, July 10th 1914, BL, AM/46113/304). He continued: "In this I have endeavoured to the best of my ability to preserve strict impartiality, to give freely, when asked, such cooperation or assistance as my own lengthening experience in public affairs may have made possible" (Gladstone speech in Cape Town, July 10th 1914, BL, AM/46113/304; my emphasis). In part, Gladstone had to use his 'lengthening experience' simply to navigate the complex political tensions in the country; he was, given his position, a prominent (although temporary) alchemist of the 'imperial formula' (Ashforth, 1997) shaping how South Africa would emerge. But he also exercised considerable effort in trying to reconfigure how South Africa would fit within a broader imperial infrastructure charged with tackling animal diseases.

Writing to Harcourt in London, for example, he presented a set of suggestions about how the imperial government might work alongside the new Union government to develop more effective powers to intervene and counteract disease. Aware that agricultural research was needed, he explored "whether something could be done to centralize and coordinate the investigations now being made by many existing bodies on animal and plant diseases" (Gladstone to Harcourt, October $30^{\text {th }} 1911$, BL, AM/45998/28). He found it "hardly necessary to point out how much is to be gained [...] by united action in these matters in order to avoid duplication, overlapping, and waste" (Gladstone to Harcourt, October $30^{\text {th }} 1911$, $\mathrm{BL}, \mathrm{AM} / 45998 / 30)$. What was needed, therefore, was a new committee operating between the Colonial and Agricultural departments in London that would "receive, digest, collate all important reports bearing directly or indirectly on 'Imperial' agriculture" (Gladstone to Harcourt, October $30^{\text {th }} 1911, \mathrm{BL}, \mathrm{AM} / 45998 /$ 31).

As Helen Tilley (2004) has noted, London did eventually create a research architecture that delivered on Gladstone's ambitions. Research commissions and international conferences helped establish an "infrastructure for research, experimentation, and biomedical provision" (Tilley, 2004: 25), as part of a broader 'veterinary regime' (Swabe, 1999) that expanded state veterinary functions across British colonial Africa. Gladstone's recommendations in 1911 and 1912, and subsequent responses from Harcourt at the Colonial Office and Runciman at the Department of Agriculture, go to show he was at the cutting edge of things. He intervened in the 'microcalities' of public administration and imagined how "efficiency and economy" (Gladstone to Harcourt, October $30^{\text {th }} 1911$, BL, AM/45998/31) in matters of research would better assist the Dominions. And he argued that a more effective coordination from a centralised office in Britain would undermine the perception that London was insufficiently interested in (what for Gladstone was) the (all-important) "material development" (Gladstone speech in Cape Town, July 10th 1914, BL, AM/46113/307) of places such as South Africa. His calculations and actions mobilized his 'lengthening experience' to create a more effective public policy regime that would stand a better chance of countering the 'swarming micros' (Dixon and Jones, 2015) at work in the tactile topologies of the rural. He responded to diverse and complex threats facing colonizer and colonized alike by developing a set of proposals for re-configuring agencies and powers of imperial government. His ambition was animated by a desire to see a better-placed machinery of government take on a more active and effective role in creating the appropriate spatial arrangements that would reengineer how flies, ticks, cattle, and people would intermingle. 
Over the long-term, European imaginaries like Gladstone's settled on the idea that animal diseases would only be "controlled or eradicated by a more highly capitalised, 'progressive' agriculture with investment in dams, fences, and paddocks" (Gilfoyle, 2003: 137). In part, this meant more "effective veterinary controls" (Brown, 2005: 516). But it also entailed expanding veterinary expertise to develop new insights about disease. Laboratory and field research in South Africa - led by Arnold Theiler, whose laboratory Gladstone referred to as "the best in the world" (Gladstone to Harcourt, October $30^{\text {th }} 1911, \mathrm{BL}, \mathrm{AM} / 45998 / 33$ ) - was central to all this (Brown, 2005). Research in South Africa frequently drew upon (and contributed to) a broader community of scientists and researchers in places such as Tanganyika, Nigeria, and Britain (Tilley, 2004). South Africa's prominent position within the broader British empire meant that tackling animal disease was not just a domestic or even only a regional issue: there was an imperial ambition and drive to alter the topological scene, for example by sending commissions of enquiry to affected areas to gain up-close knowledge of the causes, or by calling international conferences at which experts could exchange ideas and knowledge about what might be done (Tilley, 2004). Tactile topologies of the rural placed demands on the emerging state in South Africa effectively to mobilise its legal and administrative powers, especially in the area of veterinarian science (Gilfoyle, 2003; Brown, 2005).

Against this backdrop, Gladstone identified scope for reconfiguring how public policy could be used to intervene in rural space. Via adjustments to the material consequences of animal disease, the state (and the European settlers to which it principally responded) sought to alter and ultimately counter the tactile topologies of the rural. The emphasis was necessarily on finding ways of creating spatial configurations and therefore also intervening in a manner that would create a topological setting in which the disease could be tackled: better coordination, more effective interventions, and a government with more capacity to 'reach' into rural space and achieve its objectives. This all demanded that action take place nearby, within South African territory, but as Gladstone astutely pointed out, a key consideration was how action in South Africa took place in the context of and in relation to processes and events occurring within a broader field of action. Mircocalities in diverse settings were imagined; topological transformations were engineered; and the ethico-politics of intimacy - among not just Europeans, Africans, their livestock regimes, and the state, but also the lives of ticks - was questioned in efforts to create a rural space economy suited to the needs of an emerging country.

\subsection{Vast spaces and security}

Herbert Gladstone had a privileged position from which to observe and write about these emerging relationships between rural change and national development. As I have discussed, he used some of these privileges to put pressure on the imperial government to re-configure its powers. Motivating him, I argue, was that, so far as he saw it, action in rural space - ultimately, moving to transform rural space - was crucial if South Africa's economic prospects were to be realised. As he said in one of his first speeches in the country:

The establishment of the Union removes from the path of South Africa many of the obstacles which have retarded her progress and development in the past, and the new era now opening before you is rich in the possibilities of great industrial and agricultural expansion (Gladstone speech to Union Parliament, Nov 4th 1910, BL, AM/46113/155; my emphasis)
Then, as he reflected on the 1913 and 1914 strikes by mine and railway workers - two of the most unsettling moments during his time in the country - he was moved to write:

Syndicalist leaders [of the striking workers] appeared both in July and January to ignore the views of all classes excepting the crowds who assembled to listen to their oratory. The 7,000,000 natives were never mentioned. The 97,000 farmers, who are the industrial backbone of South Africa, were never mentioned. Scattered as they were through a great area, it appears to have been thought that they could be ignored by the Trades Hall. They are not capitalists. As a class they do not look with favour on mine owners. Certainly they were not hostile to the reasonable demands of white workmen. These men are proud of their country and hate disorder. They look to the Government to attend to their interests and give them protection. They constitute the mass of the population. Settled on the land, their interests are wholly and permanently South African. The attempt of a small number of individuals, with no abiding stake in the country, to subvert the government of the country, was regarded by farmers generally with unqualified disapproval and hostility (Gladstone to Harcourt, Jan 31st 1914, TNA, C0551/55/195; my emphasis).

For Gladstone, then, the project of transforming the country hinged on this permanent, settled and European class of farmers. Unlike itinerant miners, farmers would have an 'abiding stake' in the country. But if they were to remain the country's 'industrial backbone' - not least by ensuring that sufficient quantities of food reached the mines - the country's farmers needed the state's support. In this regard, it is important to locate Gladstone as a 'new liberal' (Harris, 2010/12): formerly a prominent member of a relatively progressive British government and therefore an individual who was inclined to favour an extension of the state's powers of reach. It was, though, precisely the state's limited powers of reach that seemed to trouble Gladstone the most. Gladstone frequently mentioned the country's vastness and how this shaped what the government could do. As regards the industrial action in 1913, for example, he noted that:

The government of the Union was still in the making. The great distances and sparse population were adverse to any close inter relations of component parts [...] It was a far cry from Cape Town to the Reef. [South Africa] was not for an organised entity with the sensory nerves in all directions (Gladstone's notes for biography, BL, AM/46118/226-227).

The state's reach, then, its 'sensory nerves,' was limited by these great distances. The 'component parts' could not sufficiently interact. Evidence for this was found in the low number of Police forces:

The Union Police forces are scattered throughout the country. In disturbed times it is difficult to weaken any posts, many of which are at great distances from the nearest railway. The heavy contingents of Police which are easily drafted into disturbed areas in England at short notice, do not exist in South Africa (Gladstone to Harcourt, Jan 22nd 1914, TNA CO551/54/ 163-164).

What concerned Gladstone was that, absent sufficient numbers of Police, and because "it takes some days to mobilise the Defence 
forces, irreparable mischief may have been done before the arrival of the first contingents." Consequently,

A concurrent strike on the railways not only intensifies the local peril, but at once exposes the whole country to grave danger [...] A mere glance at the railway map of South Africa should show to the least intelligent observer (1) that an effective railway strike at the chief towns of the Union, where the workers are in strength, must produce a complete stoppage of traffic; and (2) that such stoppage must isolate numberless small communities of Europeans and South African farmers generally. Not only would food supplies be curtailed, or even cut off, but it is only too obvious that if the natives seized the opportunity for robbery and worse, many thousands of white men and women scattered all over a vast area would be at their mercy (Gladstone to Harcourt, Jan 22nd 1914, TNA CO551/54/166; my emphasis).

Stability in rural space therefore hinged in large part on whether conditions could be kept stable in urban areas. Enticing new settlers to South Africa - that permanent and settled population with an abiding stake in the country - meant the state had, "to give to the whole population not only security as regards the natives, but an adequate sense of security" (Gladstone to Harcourt, Jan 31st 1914, TNA, CO551/55/197-198; my emphasis). Governing the territory, securing peace, ensuring that production occurred and therefore that exploitation continued: these demands created questions about the state's powers of reach. Power topologies were fundamentally at issue in creating the conditions under which rural development would occur in a way that would contribute to national development.

But these were also tactile topologies. The challenge, so far as Gladstone saw it, was bringing the state's powers into contact with what existed within its territory. Per Stuart Elden (2007, quoting Pasquino, 1991), the state had 'critical points' that it had to mark out and control: getting its 'nerves' into the "squares, markets, roads, bridges, rivers" (Elden, 2007: 578) required contact and this meant finding additional police, bringing in more officials, and establishing new bureaux. In reporting on the January 1914 strike, for example, Gladstone noted how the mining area, "extends for about 50 miles. The number of mines, transformers, power stations, public buildings, etc., excluding private residences in Johannesburg and on the Reef, which had to be guarded last July was about 100 . Miles of overhead power and electric lighting wires, and water mains are always open to attack" (Gladstone to Harcourt, Jan 22nd 1914, C0551/54/164-165). These were the 'critical points' around which the state's nerves had to extend. Underpinning Gladstone's vision of the new South Africa was a belief in expanding the state's capacity to create a society in which public policy could alter conditions affecting all people. It was about providing that 'adequate' sense of security, say, which hinged in part on the state's ability to stabilise a maelstrom of social relations defined by intense structural racism, deep class exploitation, and pervasive violence (Evans, 2005). It was, moreover, about altering the "entangled interplay" (Hinchliffe et al., 2013: 538) of social relations in rural and urban space. For Gladstone, at least, the state could trump the 'swarming micros' and thereby become the chief engineer of topological transformation. But its capacity to do so hinged on finding more effective spatial configurations that would compel Africans to play their part, for example by committing to using dipping tanks; mobilise a broader imperial drive to combat animal diseases, such as via efficient and economical research practice; and then the task of establishing "the constant and, if necessary, the stern preservation of the public order" (Gladstone speech in Cape Town, July 10th 1914, BL, AM/46113/307). Tactile topologies of the rural enrolled the city.

\section{Conclusion}

I have presented materials regarding the first years of the Union of South Africa which demonstrate how touch, contact, proximity, intra-action, and borderlands were germane to the political calculations shaping public policy. A striking interplay of 'swarming micros' passing between humans and other species highlights the topological challenge that faced the first government of the Union of South Africa as it imagined, and sought to create a policy framework for, agricultural development. Tactile topologies of the rural demanded action from the state. If the state - not flies or ticks - was to become the principal engine of topological transformation, numerous efforts would need to be made to alter spatial configurations and extend the state's reach into rural and urban space. Microcalities of contact, touch, proximity, and the ethicopolitics of intimacy demanded new arrangements and indeed a commitment to stark public policy, such as the drive to create the so-called 'native reserves' as a vehicle to address (or at least delay the resolution of) South Africa's peculiar constellation of social relations, bound up, as they were, with tensions regarding the wage relation, intense levels of exploitation, and race (e.g. see O'Meara, 1996; Posel, 1991). Moreover, the task of creating a space economy in which settlers would expand numerically and ramp up production was clearly bound up with urban tensions: the city was folded into rural space via numerous 'security' issues that came to light in diverse ways, as Gladstone found when he was confronted with industrial action in 1913 and 1914. Likewise, action in rural space intra-acted with the city: with the need for food to reach the mines, in particular. The case of early modern South Africa demonstrates how tactile topologies of the rural mattered.

There is a strong case to be made for viewing aspects of the topological scene I examined above as continuing to matter in rural South Africa. Tactile topologies of the rural were altered and recalibrated around a century ago via interactions and intra-actions emerging from the dynamics of the new Union government's place in the world; but governments today must still grapple with matters of tactility and intimacy, for example in the country's ostrich industry (e.g. see Mather and Marshall, 2011; Mather, 2014). Furthermore, insofar as colonial and apartheid era veterinary science struggled to understand and in many ways worked to disadvantage African livestock practices relative to the apparently safer (or, in today's parlance, more biosecure) European approach, one lingering result is a racialised attitude among some white commercial farmers in rural South Africa that African agricultural practices are inferior and to be avoided; an attitude, moreover, that has shaped landmark government policies aimed at altering the country's rural geography (Fraser, 2007). Finally, in rural (and urban) spaces throughout the country there are persistent tensions between South Africans and immigrants (e.g. see Kirshner, 2012; Alfaro-Velcamp and Shaw, 2016), which reflect, at least in part, the country's contact with a version of neoliberalism that limits government spending, consistently fails to deal with widespread unemployment, but also embraces distant actors such as supermarkets to reach into the country and promote development projects that intra-act with workforce paternalism (e.g. see Bolt, 2016).

Beyond South Africa, too, bringing tactile topologies of the rural into analytical focus opens up new vistas from which to grasp the complex interplay between human and non-human actors in rural space. And doing so prompts new questions about past and contemporary processes of socio-spatial change. The fact of contact demands the (transient, fleeting) construction of spatial configurations that necessarily open up a vast range of new possibilities and contingencies. A well-known example concerns the effect of germs Europeans brought with them to the Americas, which likely stands out as one of the most obvious ways that tactile topologies 
can be understood to have had profound consequences (Galeano, 1973). More generally, colonialism was wrapped up with complex interplays involving 'contact' (often of a violent nature) between those who stood to acquire and accumulate land or resources, those who stood to lose out, and then the various 'swarming micros' altering life for human and non-human actors (e.g. see Duncan, 2002). Pests, bacteria, and numerous other non-human lives were engines of topological transformation. Rurality was caught up in all this, albeit in complex - and largely under-researched - ways (although see Morris, 2007; Gahman, 2015).

Issues of tactility also cut across many of the most significant recent developments shaping rural space and, as such, rural studies. Consider the debate regarding 'land grabs' (e.g. see Borras et al., 2011) or 'accumulation by dispossession' (Harvey, 2003) and how tactility - grabbing, possessing - informs but remains under-theorised in research on these concepts and the diverse contexts in which they are taking shape. Also intertwined with tactility is the emerging use of genetically modified organisms (GMOs) in agriculture: at issue, in part, are fears about whether seeds from GMO crops might conceivably make contact with nonGMO crops and therefore create entirely new and unpredictable intra-actions with potentially far-reaching consequences for food production globally (e.g. see Hall and Moran, 2006). A final example might involve the end of the 'yield honeymoon' (Moore, 2010), which is partly a product of the declining efficacy of pesticides and, as such, the ability of pests to withstand contact with humanengineered chemicals, the widespread use of which stems from a 'high-modernist' (Scott, 1998) belief in 'technological fixes' (Weis, 2007) - in other words, pests have adjusted to the emerging topological scene and found ways to live and thrive despite forms of contact that humans believed would wipe them out. In short, as these examples signpost, tactility pervades rurality. If contact is necessarily constitutive of space as a whole, it makes sense to consider how rural space is shaped by concerns regarding, or the actual material and discursive consequences of, contact and intimacy. Future research is needed to begin shedding further light on these dynamics.

\section{Funding}

This research did not receive any specific grant from funding agencies in the public, commercial, or not-for-profit sectors.

\section{References}

Alfaro-Velcamp, T., Shaw, M., 2016. Please GO HOME and BUILD Africa': criminalising immigrants in South Africa. J. South. Afr. Stud. 42, 983-998.

Allen, J., 2003. Lost Geographies of Power. Malden, MA, Blackwell.

Allen, J., 2008. Responsabilité au travail et mondialisation: au-delà du système de sweatshop. In: Benelli, Natalie, Rosende, Magdalena (Eds.), Laboratories du Travail. Antipodes, Lausanne, pp. 93-104.

Allen, J., 2011a. Powerful assemblages? Area 42, 154-157.

Allen, J., 2011b. Topological twists: power's shifting geographies. Dialogues Hum. Geogr. 1, 283-298.

Allen, J., Cochrane, A., 2010. Assemblages of state power: topological shifts in the organization of government and politics. Antipode 42, 1071-1089.

Allen, J., Cochrane, A., 2014. The urban unbound: London's politics and the 2012 olympic games. Int. J. Urban Reg. Res. 38, 1609-1624.

Allen, J., Lavua, S., 2015. 'Just-in-Time' disease. J. Cult. Econ. 8, 342-360.

Ashforth, A., 1997. Lineaments of the political geography of state formation in twentieth-century South Africa. J. Hist. Sociol. 10, 101-126. https://doi.org/ 10.1111/1467-6443.00033.

Barad, K., 2007. Meeting the Universe Halfway: Quantum Physics and the Entanglment of Matter and Meaning. Duke University Press, Durham NC.

Barker, K., 2008. Flexible boundaries in biosecurity: accommodating gorse in Aotearoa New Zealand. Environ. Plan. A 40, 1598-1614.

Barker, K., 2015. Biosecurity: securing circulations from the microbe to the macrocosm. Geogr. J. 181, 357-365.

Bentley, M., 1992. Gladstone's heir. Engl. Hist. Rev. 107, 901-924.

Bolt, M., 2016. Accidental neoliberalism and the performance of management: hierarchies in export agriculture on the Zimbabwean-South African border. J. Dev.
Stud. 52, 561- 575

Borras, S.M., Hall, R., Scoones, I., White, B., Wolford, W., 2011. Towards a better understanding of global land grabbing: an editorial introduction. J. Peasant Stud. 38, 209-216. https://doi.org/10.1080/03066150.2011.559005.

Brenner, N., Schmid, C., 2014. The 'Urban age' in question. Int. J. Urban Reg. Res. 38 731-755. https://doi.org/10.1111/1468-2427.12115.

Brown, K., 2005. Tropical medicine and animal diseases: onderstepoort and the development of veterinary science in South Africa 1908-1950. J. South. Afr. Stud. 31, 513-529. https://doi.org/10.1080/03057070500202139.

Brown, K., Gilfoyle, D., 2010. Healing the Herds: Disease, Livestock Economies, and the Globalization of Veterinary Medicine. Ohio University Press, Athens, OH.

Cranefield, P.F., 1991. Science and Empire: East Coast Fever in Rhodesia and the Transvaal. Cambridge University Press, Cambridge.

Davis, D.K., 2008. Brutes, beasts and empire: veterinary medicine and environmental policy in French North Africa and British India. J. Hist. Geogr. 34, 242-267. https://doi.org/10.1016/j.jhg.2007.09.001.

Dixon, D., Jones III, J.P., 2015. The tactile topologies of contagion. Trans. Inst. Br. Geogr. 40, 223-234

Duncan, J., 2002. Embodying colonialism? Domination and resistance in nineteenth-century Ceylonese coffee plantations. J. Hist. Geogr. 28, 317-338. https://doi.org/10.1006/jhge.2001.0455.

Elden, S., 2007. Governmentality, calculation, territory. Environ. Plan. D Soc. Space 25, 562-580. https://doi.org/10.1068/d428t.

Enticott, G., 2008. The spaces of biosecurity: prescribing and negotiating solutions to bovine tuberculosis. Environ. Plan. A 40, 1568-1582.

Enticott, G., 2011. Techniques of neutralising wildlife crime in rural England and Wales. J. Rural. Stud. 27, 200-208.

Enticott, G., 2012. The local universality of veterinary expertise and the geography of animal disease. Trans. Inst. Br. Geogr. 37, 75-88.

Enticott, G., 2016. Market instruments, biosecurity and place-based understandings of animal disease. J. Rural. Stud. 45, 312-319.

Evans, I., 2005. Racial violence and the origins of segregation in South Africa. In: Elkins, C., Pedersen, S. (Eds.), 2005. Settler Colonialism in the Twentieth Century. Routledge, London, pp. 183-202.

Fraser, A., 2007. Land reform in South Africa and the colonial present. Soc. Cult. Geogr. 8, 835-851.

Gahman, L., 2015. Gun rites: hegemonic masculinity and neoliberal ideology in rural Kansas. Gend. Place Cult. 22, 1203-1219. https://doi.org/10.1080/ 0966369X.2014.970137.

Galeano, E., 1973. Open Veins of Latin America: Five Centuries of the Pillage of a Continent. Monthly Review Press, New York.

Gilfoyle, D., 2003. Veterinary research and the african rinderpest epizootic: the Cape colony, 1896-1898. J. South. Afr. Stud. 29, 133-154. https://doi.org/ $10.1080 / 0305707032000060494$

Hall, C., Moran, D., 2006. Investigating GM risk perceptions: a survey of anti-GM and environmental campaign group members. J. Rural. Stud. 22, 29-37. https://doi.org/10.1016/j.jrurstud.2005.05.010.

Harris, J., 2010/12. The liberal empire and British social policy: citizens, colonials, and indigenous peoples, circa 1880-1914. Hist.@Polit. 11, 1-14.

Harvey, D., 2003. The New Imperialism. Oxford University Press, Oxford.

Heley, J., Jones, L., 2012. Relational rurals: some thoughts on relating things and theory in rural studies. J. Rural. Stud. 28, 208-217.

Higginson, J., 2001. Hell in small places: agrarian elites and collective violence in the western Transvaal, 1900-1907. J. Soc. Hist. 35, 95-124. https://doi.org/10.1353/ jsh.2001.0084.

Hinchliffe, S., Allen, J., Lavau, S., Bingham, N., Carter, S., 2013. Biosecurity and the topologies of infected life: from borderlines to borderlands. Trans. Inst. Br. Geogr. 38, 531-543.

Hinchliffe, S., Ward, K.J., 2014. Geographies of folded life: how immunity reframes biosecurity. Geoforum 53, 136-144. https://doi.org/10.1016/ j.geoforum.2014.03.002

Jackson, P., 2006. Loulou: Selected Extracts from the Journals of Loulou Harcourt (1880-1895). Farleigh Dickinson University Press, Madison, WI.

Jenkins, R., 1978. Asquith. Collins, London.

Jenkins, R., 1995. Gladstone. Mcmillan, London.

Jönsson, E., 2016. Trump in Scotland: a study of power-topologies and golf topographies. Int. J. Urban Reg. Res. 40, 559-577.

Kirshner, J.D., 2012. "We are gauteng people": challenging the politics of xenophobia in Khutsong, South Africa. Antipode 44, 1307-1328.

Law, J., 2006. Disaster in agriculture: or foot and mouth mobilities. Environ. Plan. A $38,227-239$.

Law, J., Mol, A., 2008. Globalisation in practice: on the politics of boiling pigswill. Geoforum 39, 133-143. https://doi.org/10.1016/j.geoforum.2006.08.010.

MacFarlane, C., 2016. The geographies of urban density: topology, politics and the city. Prog. Hum. Geogr. 40, 629-648.

Mallet, C.E., 1932. Herbert Gladstone: a Memoir. Hutchinson \& Co., London.

Marston, S.A., Jones III, J.P., Woodward, K., 2005. Human geography without scale. Trans. Inst. Br. Geogr. 30, 416-432.

Martin, L., Secor, A.J., 2014. Towards a post-mathematical topology. Prog. Hum. Geogr. 38, 420-438.

Mather, C., Marshall, A., 2011. Living with disease? Biosecurity and avian influenza in ostriches. Agric. Hum. Values 28, 153-165.

Mather, C., 2014. Avian influenza multiple: enacting realities and dealing with policies in South Africa's farmed ostrich sector. J. Rural. Stud. 33, 99-106.

Moore, J.W., 2010. The end of the Road? Agricultural revolutions in the capitalist 
world-ecology, 1450-2010. J. Agrar. Change 10, 389-413.

Morris, R.C., 2007. Imperial pastoral: the politics and aesthetics of translation in British Malaya. Representations 99, 159-193. https://doi.org/10.1525/ rep.2007.99.1.159.

Mwatwara, W., Swart, S., Nov. 2015. 'If our cattle die, we eat them but these white people bury and burn them!' African livestock regimes, veterinary knowledge and the emergence of a colonial order in Southern Rhodesia, c. 1860-1902. Kronos 41 (1), 112-141. Cape Town, Available from: http://www.scielo.org.za/ scielo.php?script $=$ sci_arttext $\&$ pid $=$ S0259 $01902015000100005 \& \operatorname{lng}=$ en\&nrm $=$ iso.

O'Meara, D., 1996. Forty Lost Years: the Apartheid State and the Politics of the National Party, 1948-1994. Ohio University Press, Athens, OH.

Ogborn, M., 2008. Global Lives: Britain and the World 1550-1800. Cambridge University Press, Cambridge.

Pasquino, P., 1991. Theatrum politicum: the genealogy of capital. In: Burchell, G., Gordon, C., Miller, P. (Eds.), 1997. The Foucault Effect: Studies in Governmentality. University of Chicago Press, Chicago, pp. 105-118.

Posel, D., 1991. The Making of Apartheid, 1948-1961: Conflict and Compromise. Clarendon Press, Oxford.

Scott, J.C., 1998. Seeing like a State: How Certain Schemes to Improve the Human Condition Have Failed. Yale University Press, New Haven, Conn.

Scott, A., Christie, M., Midmore, P., 2004. Impact of the 2001 foot-and-mouth disease outbreak in Britain: implications for rural studies, 20, 1-14. https:// doi.org/10.1016/S0743-0167(03)00032-9.

Sunseri, T., 2013. A political ecology of beef in colonial Tanzania and the global periphery, 1864-1961. J. Hist. Geogr. 39, 29-42. https://doi.org/10.1016 j.jhg.2012.08.017.

Swabe, J., 1999. Animals, Disease and Human Society: Human-animal Relations and the Rise of Veterinary Medicine. Routledge, London.

Tilley, H., 2004. Ecologies of complexity: tropical environments, african trypanosomiasis, and the science of disease control in British colonial Africa, 1900-1940. Osiris 2, 21-38.

Waller, R., 2004. 'Clean' and 'dirty': cattle disease and control policy in Colonial Kenya, 1900-40. J. Afr. Hist. 45, 45-80. https://doi.org/10.1017 S0021853703008508. Published: 2004.

Weis, A., 2007. The Global Food Economy: the Battle for the Future of Farming. Zed, London.

Weis, A., 2013. The Ecological Hoofprint: the Global Burden of Industrial Livestock. Zed, London.

Wilbert, C., 2006. Profit, plague and poultry. Radic. Philos. 139, 2-8.

Woods, M., 2003. Deconstructing rural protest: the emergence of a new social movement. J. Rural. Stud. 19, 309-325.

Woods, M., 2007. Engaging the global countryside: globalization, hybridity, and the reconstitution of rural space. Prog. Hum. Geogr. 31, 485-507. 